\title{
Pyrolysis behavior and kinetic study of phenol as tar model compound in micro fluidized bed reactor
}

\author{
Chao Gai ${ }^{a}$, Yuping Dong ${ }^{b, *}$, Zhaochuan Lv ${ }^{b}$, Zhaoling Zhang ${ }^{c}$, \\ Jingcui Liang ${ }^{c}$, Yantao Liu ${ }^{c}$ \\ ${ }^{a}$ Research Center for Eco-Environmental Sciences, Chinese Academy of Sciences, 18 Shuangqing Road, Beijing \\ 100085, PR China \\ b School of Mechanical Engineering, Shandong University, Jinan 250061, PR China \\ c Shandong Baichuan Tongchuang Energy Company Ltd., Jinan 250101, PR China
}

\section{A R T I C L E I N F O}

Article history:

Received 26 January 2015

Received in revised form

2 April 2015

Accepted 17 April 2015

Available online 12 May 2015

\section{Keywords:}

Tar

Phenol

Pyrolysis

Kinetics

Micro fluidized bed reactor

\begin{abstract}
A B S T R A C T
Thermal cracking characteristic of phenol as the model compound of biomass tar was investigated on a micro fluidized bed reactor. Pyrolysis kinetics for individual gaseous component, including hydrogen, methane, carbon monoxide and carbon dioxide were determined based on the iso-conversional and model-fitting approaches. Results indicated that carbon monoxide accounted for the biggest percentage of the total gas yield during pyrolysis of phenol. The evolution profiles of hydrogen energy and carbon monoxide were more affected by reaction temperature compared to methane and carbon dioxide. In the major conversion fraction from $20 \%$ to $80 \%$, the apparent activation energies of methane $(49.67 \mathrm{~kJ} / \mathrm{mol})$ and carbon dioxide $(30.87 \mathrm{~kJ} / \mathrm{mol})$ were lower than that of hydrogen $(145.2 \mathrm{~kJ} /$ $\mathrm{mol}$ ) and carbon monoxide $(53.35 \mathrm{~kJ} / \mathrm{mol})$. The most probable reaction mechanism for the formation of hydrogen and methane was three-dimension diffusion while chemical reaction and contracting sphere could describe the generation of carbon monoxide and carbon dioxide, respectively.
\end{abstract}

Copyright $\odot$ 2015, Hydrogen Energy Publications, LLC. Published by Elsevier Ltd. All rights reserved.

\section{Introduction}

Gasification is generally viewed as one of the most promising options for converting biomass to gaseous biofuels. However, the generation of tar is a bottleneck problem during this thermo-chemical conversion process [1-3]. As a typical byproduct, tar will be condensed when the temperature is lower than its dew point, rendering the blockage of downstream equipments such as engines, filters and turbines [4], which will severely affect the stable operation of equipments
[5]. Besides, the generation of tar causes a partial loss of input energy [6,7]. Tar removal has been a key issue for utilizing biomass.

As one of the tar reduction methods, thermal cracking can convert tar into lighter gases with small molecules (e.g. hydrogen, methane and carbon monoxide) under high temperatures and certain residence time. This approach can reduce the content of tar without secondary pollution and waste of extra energy retained in the tar [8-10]. It is a potential method to improve the efficiency of thermo-chemical of

\footnotetext{
* Corresponding author. Tel.: +86 531 88392199; fax: +86 53188873588.

E-mail address: dongyp@sdu.edu.cn (Y. Dong). 
biomass and get extensive studies. Additionally, with the presence of catalysts (e.g. acid catalysts, metal catalysts and activated carbon catalysts), the reaction temperature and residence time can be further decreased to reduce the energy consumption [11-13]. It should be noted that as high temperature is required to crack the tar, the concept of two-stage gasification facilities contributes to better results with respect to this issue. It usually separates the pyrolysis and gasification processes into two varied stages, and tar can be thermal decomposed into gases under higher temperatures by partial combustion of the volatiles between the two stages. This arrangement contributes to the production of gas products with a higher caloric value and lower tar content [14-16].

During this process, kinetic analysis is a promising way to elucidate the reaction mechanisms, which are usually investigated by thermogravimetric analysis (TGA) [17,18]. The thermogravimetric analyzer can monitor the evolution of sample mass in real time. However, the main disadvantage is that the sample needs to be feed into the reaction chamber at normal temperature and there is a small mass-lose before reaching the preset temperature. Besides, due to the limitation of structure and design principle, TGA could not be carried out under the condition of high gas velocity $[19,20]$. To address this deficiency brought by TGA, Institute of Process Engineering in Chinese Academy of Sciences, Shandong University and Shandong Baichuan Tongchuang Energy Company developed the micro fluidized bed reactor (MFBR). This instrument is mainly composed of a micro fluidized bed and a process mass spectrometer. It can send the samples into the reactor instantaneously when the temperature within the reactor is heated to the preset level. Therefore, the reaction time can be greatly shortened. The process mass spectrometer can analyze the relative concentration of gaseous products online. Then the kinetic parameters can be determined based on the evolution profiles of gaseous product under different temperatures. MFBR can minimize the inhibition of the diffusion and realize the isothermal reaction process in situ [21].

Tar is composed of numerous organic compounds with high boiling points. The main compositions of tar are polycyclic aromatic hydrocarbons (PAHs) in terms of phenol, toluene, benzene, naphthalene, anthracene and styrene [22-24]. Since the tar composition is extremely complex, most studies select one or two compounds of PAHs as the tar model compound, such as toluene $[25,26]$, benzene $[27,28]$ and naphthalene $[29,30]$, but few studies are concerned with the compound of phenol, which is one of the major compositions of tar [31]. This work selected phenol as the tar model compound. The pyrolysis behavior of phenol was investigated in MFBR. Then the kinetic parameters as well as the most probable reaction mechanisms for the reaction processes were determined.

\section{Methods}

\section{Experimental facility}

Fig. 1 illustrates the schematic diagram of micro fluidized bed reactor system (MFBR). It is mainly composed of a sample feeding system, a micro fluidized bed and a process mass spectrometer (Dycor ProLine, Ametek, USA). The feeding system is driven by an electromagnetic valve that can release about $10 \mathrm{ml}$ gas per single pulse to send the sample into the reactor within $0.1 \mathrm{~s}$. The pulsed gas originated from a compressed gas stream with the pressure of $0.2 \mathrm{MPa}$. The fluidized bed reactor is the key part of the MFBR, which is made of quartz and it is capable of bearing high temperatures around $1200^{\circ} \mathrm{C}$ for a long time. The overall height and diameter of the fluidized bed reactor are $373 \mathrm{~mm}$ and $290 \mathrm{~mm}$, respectively. The internal height and diameter of the reaction zone are $42 \mathrm{~mm}$ and $20 \mathrm{~mm}$, respectively. The mass spectrometer can measure the relative content of gaseous products during the pyrolysis of tar online. The temperatures of the reactor and furnace, the pressures of the reactor as well as the actions of the sample feeding system are all controlled by the computer.

\section{Experimental procedure}

In this study, quartz sand was selected as the fluidization medium due to the poor catalytic influence on tar cracking. The particle sizes were ranged from $0.2 \mathrm{~mm}$ to $0.25 \mathrm{~mm}$. At the beginning of each test, $3.0 \mathrm{~g}$ of quartz sand as the fluidizing medium was loaded into the fluidized bed reactor. $10 \pm 0.1 \mathrm{mg}$ phenol (Analytical pure, Tianjin Damao Chemical Reagent Factory, China) was placed at the sample-feeding system. After the system was sealed, the fluidizing gas, argon with 99.99\% purity, was fed to the reactor to fluidize the quartz sand in the reactor. After several preliminary tests, the gas flow rate was kept at $500 \mathrm{ml} / \mathrm{min}$ to ensure all quartz sands were fully fluidized, providing an optimum reaction condition. Afterwards, the reactor was heated to the preset temperatures. Then the pulse valve of the sample-feeding system was switched on to inject the sample into the reaction zone in MFBR, which initiated the pyrolysis reactions. The evolution of produced gas was monitored online by a mass spectrometer. According to Fuentes-Cano et al. [29] and Jess [32], the thermal cracking of polycyclic aromatic hydrocarbons lead to hydrocarbons with smaller carbon numbers and the intermediates are formed only to a limited extent. Consequently, the light gases including hydrogen $\left(\mathrm{H}_{2}\right)$, methane $\left(\mathrm{CH}_{4}\right)$, carbon monoxide $(\mathrm{CO})$ and carbon dioxide $\left(\mathrm{CO}_{2}\right)$ are investigated in the present study. The four gaseous products were all sampled in the entire reaction time to be analyzed via Micro-GC 3000 for quantifying the corresponding yield. The total gas yield was the sum of yields of the four gaseous products investigated in the present study.

According to Fagbemi et al. [33], the thermal cracking of tar is effective above $500{ }^{\circ} \mathrm{C}$. Jess [32] concluded that the temperatures within $1200{ }^{\circ} \mathrm{C}$ were necessary for the thermal decomposition of aromatic hydrocarbons as tar model compounds. Dufour et al. [31] carried out a pyrolysis experiment of woody biomass in a quartz tubular reactor and investigated the evolution of aromatic tar composition as a function of reaction temperature. It was reported that with the temperature increasing from $700{ }^{\circ} \mathrm{C}$ to $1000{ }^{\circ} \mathrm{C}$, the mole fraction of phenol in the total amount of quantified aromatic tar was gradually decreased from around $25 \%$ to $1 \%$. Vivanpatarakij et al. [34] carried out a thermodynamic analysis of biomass gasification, and it was concluded that at a lower operating 


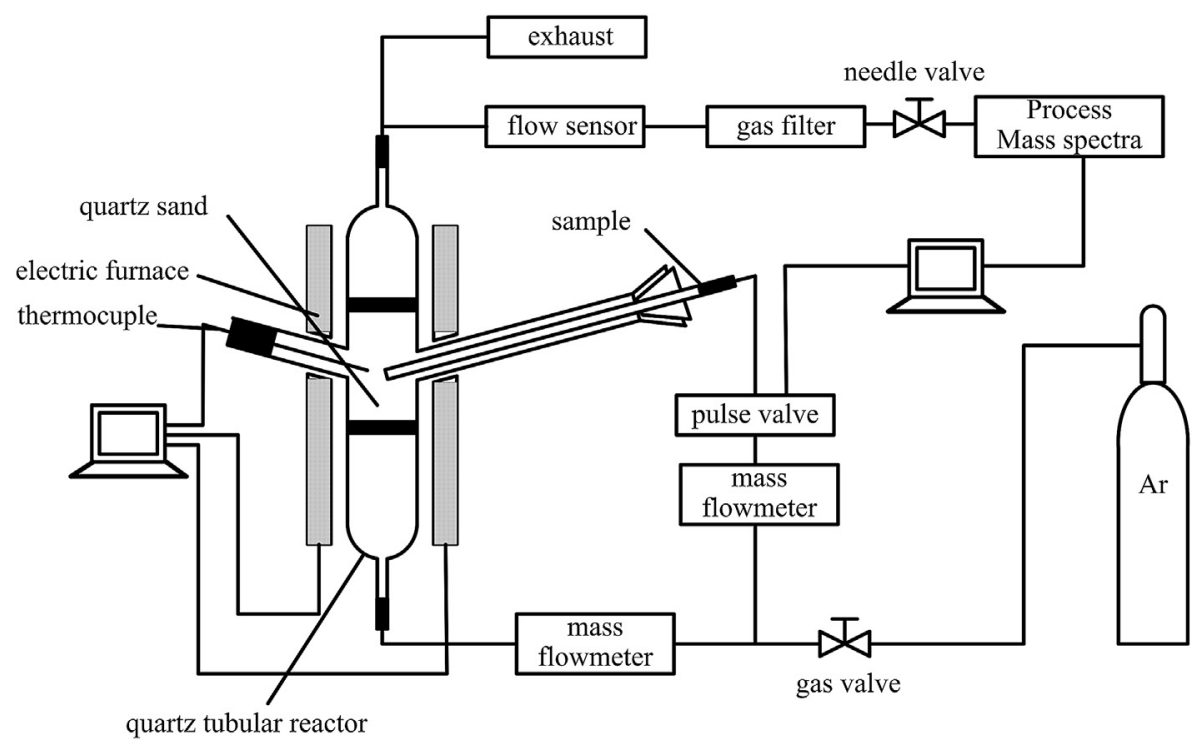

Fig. 1 - Scheme for the micro fluidized bed reactor system.

temperature $(973 \mathrm{~K})$, phenol was the major tar component and at a higher temperature $(1173 \mathrm{~K})$, most phenol was thermal cracked into light gases. Therefore, the preset temperatures in the present study for thermal decomposition of phenol were selected between $750{ }^{\circ} \mathrm{C}$ and $950{ }^{\circ} \mathrm{C}$ with $50{ }^{\circ} \mathrm{C}$ intervals.

\section{Kinetic methods}

Activation energy is one of the most significant kinetic parameters evaluating the reactivity, which is usually calculated based on model-fitting method or model-free/isoconversional method. The latter approach can determine the apparent activation energy without the assumption of reaction model, thus it can eliminate the inaccuracy of "kinetic compensation effect" [35] brought by the application of model-fitting method. Friedman-Reich-Levi method [36] is a typical iso-conversional method, which is used to determine the kinetic parameters in the present study. Since the pyrolysis of phenol in MFBR is a heterogeneous solid-state reaction, the global kinetics of the reaction can be described as $[17,37]$ :

$d x / d t=k(T) \times f(x)$

where $k(T)$ is the rate constant of reaction, $f(x)$ is the differential reaction model, $\mathrm{T}$ is the reaction temperature, $\mathrm{t}$ is the reaction time, $\mathrm{x}$ is the conversion fraction of gas concentration. It was defined by the produced gas volume against the total gas volume at the end of the reaction [19], which can be calculated through:

$x=\frac{\int_{t_{0}}^{t} V_{i} \times V d t}{\int_{t_{0}}^{t_{e}} V_{i} \times V d t} \times 100 \%$

where $\mathrm{V}_{\mathrm{i}}$ is the volume rate of the gas product $\mathrm{i}, \mathrm{V}$ is the volume rate of all gas products, $t_{0}$ is the start time of reaction, and $t_{e}$ is the end time of reaction.
In Eq. (1), $\mathrm{k}(\mathrm{T})$ is determined by Arrhenius equation:

$k(T)=A \exp \left(-E_{a} / R T\right)$

where $E_{a}$ is the apparent activation energy, $A$ is the preexponential factor, $\mathrm{R}$ is the universal gas constant.

Substituting of Eq. (3) into Eq. (1), then, taking the logarithm of both sides results in the expression for the Friedman-ReichLevi method:

$\ln (d x / d t)=-E_{a} / R T+\ln A+\ln f(x)$

The points of $\ln (\mathrm{dx} / \mathrm{dt})$ versus $1 / \mathrm{T}$ at different reaction temperatures can be fitted to a straight line, and the slope of the line corresponds to $-E_{a} / R$. Therefore, the apparent activation energy $E_{a}$ can be finally deduced from the slope of the straight line.

The most probable reaction mechanism for pyrolysis of phenol in MFBR was evaluated based on the universal integral method [38,39], which is a typical model-fitting approach.

Eq. (1) can be further converted into Eq. (5) as:

$d x / f(x)=k(T) \times d t$

Taking the integration of the both sides of Eq. (5), and it can be further integrated into:

$G(x)=\int_{0}^{x} \frac{d x}{f(x)}=k(T) \times t$

where $G(x)$ is the integral reaction model. Based on Eq. (6), the points of $\mathrm{G}(\mathrm{x})$ versus $\mathrm{t}$ at different reaction temperatures can be fitted to a straight line, and the slope of the line corresponds to $\mathrm{k}(\mathrm{T})$.

Taking the logarithm of both sides of Eq. (3) can lead to the expression:

$\ln k(T)=-E_{a} / R T+\ln A$

Then based on Eq. (7), the plots between $\ln \mathrm{k}(\mathrm{T})$ versus $1 / \mathrm{T}$ generate a straight line with the slope $-\mathrm{E}_{\mathrm{a}} / \mathrm{R}$ to determine the 
Table 1 - Product distribution for pyrolysis of phenol at different temperatures.

\begin{tabular}{lrrrrr} 
Temperature $\left({ }^{\circ} \mathrm{C}\right)$ & 750 & 800 & 850 & 900 & 950 \\
\hline Total gas yield $(\%)$ & 65.27 & 68.78 & 73.22 & 79.16 & 83.21 \\
$\mathrm{H}_{2}(\%)$ & 3.72 & 4.13 & 4.47 & 6.10 & 6.82 \\
$\mathrm{CH}_{4}(\%)$ & 1.11 & 1.58 & 2.20 & 2.61 & 3.41 \\
$\mathrm{CO}(\%)$ & 42.62 & 47.46 & 56.23 & 62.38 & 65.99 \\
$\mathrm{CO}_{2}(\%)$ & 17.82 & 15.61 & 10.32 & 8.07 & 6.99
\end{tabular}

apparent activation energy once again. The most probable reaction model $\mathrm{G}(\mathrm{x})$ can be determined based on the closeness of the value of apparent activation energies obtained from the universal integral method and Friedman-Reich-Levi approach.

\section{Results and discussion}

\section{Product distribution}

The yields of produced light gas at different reaction temperatures during pyrolysis of phenol in MFBR were shown in Table 1. It can be seen that CO was the major composition of pyrolysis gas mixture from phenol, which made up a large percentage of total gas yield. Horn et al. [40] carried out hightemperature shock-tube pyrolysis of phenol and $\mathrm{CO}$ was observed to be the principal products, which is consistent with the present work. However, Jess [32] investigated the thermal degradation of aromatic hydrocarbons as tar model compounds, and it was reported that with increasing temperature, the organic cracking products from naphthalene were more converted to $\mathrm{CO}$ while $\mathrm{CH}_{4}$ and $\mathrm{C}_{2} \mathrm{H}_{4}$ are the major cracking products from benzene. It suggests that the product distribution is also concerned with the chemical composition of the tar model compounds.

With increasing the reaction temperature, the total gas yield gradually increased from $65.27 \%$ at $750{ }^{\circ} \mathrm{C}$ to $83.22 \%$ at $950{ }^{\circ} \mathrm{C}$. It suggests that the cracking reaction of tar model compound is favored at higher temperatures. However, the variations of gaseous products were not a monotonic trend. Specifically, the yield of $\mathrm{H}_{2}$ increased gradually from $3.72 \%$ at $750{ }^{\circ} \mathrm{C}$ to $6.82 \%$ at $950{ }^{\circ} \mathrm{C}$. This trend agrees well with the variation of $\mathrm{H}_{2}$ yield during the pyrolysis of real biomass like straw [33] or model compound like toluene [11]. The yield of $\mathrm{CH}_{4}$ and $\mathrm{CO}$ was also increased from $1.11 \%$ and $42.62 \%$ to $3.41 \%$ and $65.99 \%$, respectively. A gradual decrease from $17.82 \%$ to $6.99 \%$ was observed for $\mathrm{CO}_{2}$.

\section{Pyrolysis behavior of phenol}

Fig. 2 showed the effect of temperature on the relationship of the conversion fraction versus reaction time for different gaseous products (i.e. $\mathrm{H}_{2}, \mathrm{CH}_{4}, \mathrm{CO}$ and $\mathrm{CO}_{2}$ ) during pyrolysis of
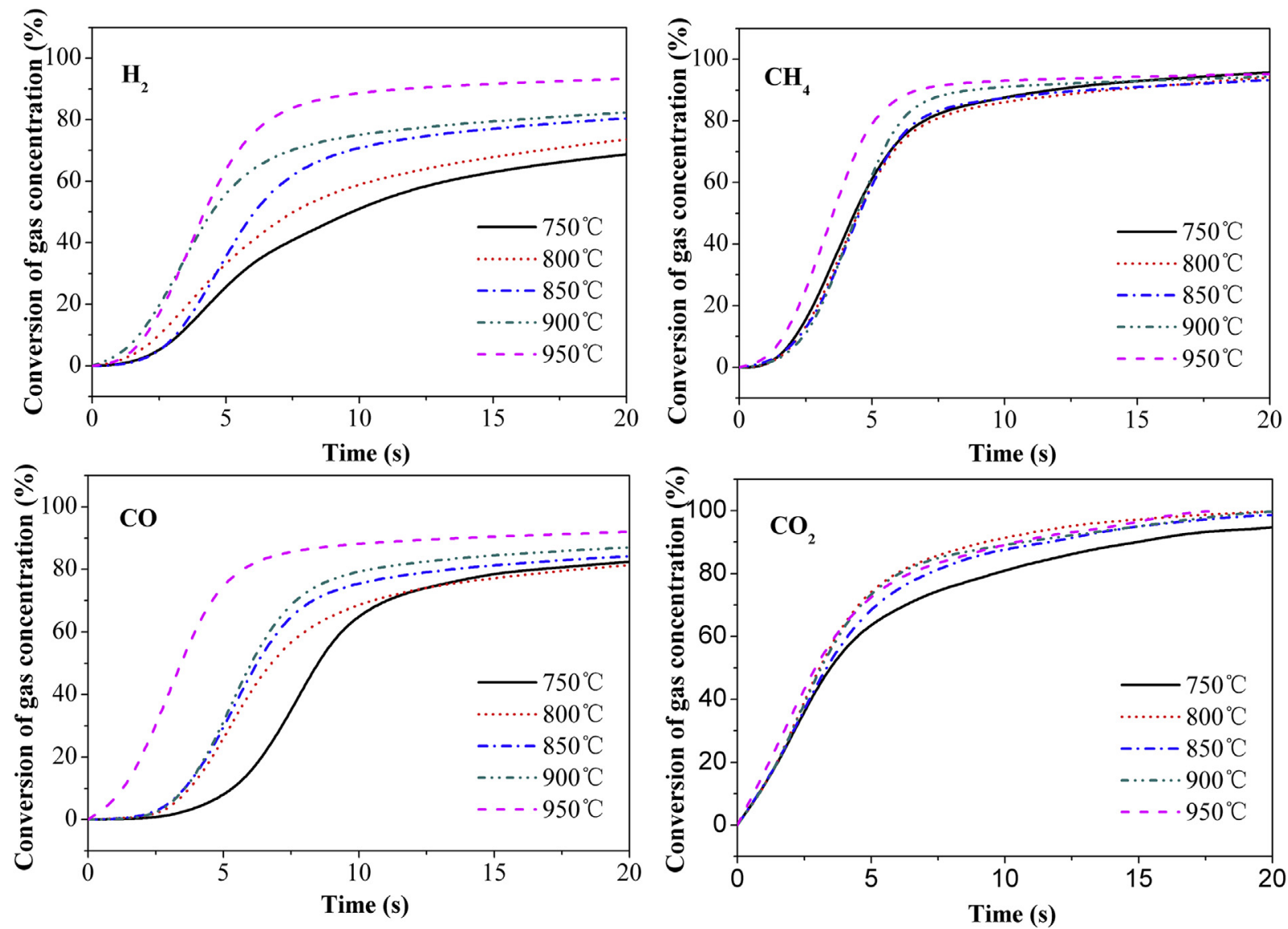

Fig. 2 - Evolution of conversion fractions versus reaction time at different temperatures for pyrolysis of phenol. 
Table 2 - Apparent activation energies for individual gas during pyrolysis of phenol.

\begin{tabular}{|c|c|c|c|c|c|c|c|c|c|}
\hline Gas & Conversion (wt.\%) & $\mathrm{R}^{2}$ & SD & $E_{a}(\mathrm{~kJ} / \mathrm{mol})$ & Gas & Conversion (wt.\%) & $\mathrm{R}^{2}$ & SD & $\mathrm{E}_{\mathrm{a}}(\mathrm{kJ} / \mathrm{mol})$ \\
\hline \multirow[t]{8}{*}{$\mathrm{H}_{2}$} & 20 & 0.924 & 0.043 & 15.29 & $\mathrm{CH}_{4}$ & & 0.905 & 0.042 & 20.83 \\
\hline & 30 & 0.920 & 0.044 & 55.41 & & & 0.926 & 0.041 & 25.51 \\
\hline & 40 & 0.982 & 0.021 & 117.5 & & & 0.943 & 0.036 & 29.69 \\
\hline & 50 & 0.989 & 0.013 & 155.1 & & & 0.991 & 0.021 & 41.04 \\
\hline & 60 & 0.991 & 0.011 & 211.1 & & & 0.983 & 0.019 & 65.82 \\
\hline & 70 & 0.999 & 0.024 & 213.0 & & & 0.993 & 0.013 & 76.82 \\
\hline & 80 & 0.934 & 0.022 & 249.1 & & & 0.986 & 0.027 & 87.95 \\
\hline & Average & & & 145.2 & & Average & & & 49.67 \\
\hline \multirow[t]{8}{*}{$\mathrm{CO}$} & 20 & 0.947 & 0.042 & 1.578 & $\mathrm{CO}_{2}$ & & 0.988 & 0.003 & 0.077 \\
\hline & 30 & 0.938 & 0.035 & 1.624 & & & 0.984 & 0.027 & 6.352 \\
\hline & 40 & 0.993 & 0.039 & 18.03 & & & 0.993 & 0.048 & 11.66 \\
\hline & 50 & 0.991 & 0.014 & 33.13 & & & 0.998 & 0.051 & 14.12 \\
\hline & 60 & 0.993 & 0.027 & 55.78 & & & 0.983 & 0.018 & 21.48 \\
\hline & 70 & 0.971 & 0.040 & 115.0 & & & 0.988 & 0.051 & 69.95 \\
\hline & 80 & 0.949 & 0.039 & 148.4 & & & 0.994 & 0.044 & 92.44 \\
\hline & Average & & & 53.35 & & Average & & & 30.87 \\
\hline
\end{tabular}

phenol in MFBR. The conversion fraction of $100 \%$ means the highest gas yield at the end of reaction. It can be seen that for all gas components, the conversion fractions increased rapidly within the first 10 s, then tended to a slow growth. It is because that the model compound of phenol was sent into the reaction zone at the preset temperature rather than the ambient temperature. Thus a higher rate of heat and mass transfer could be fulfilled, enabling the fast decomposition of phenol into light gas, especially at the initial stage of reaction. It also indicates that the reaction in MFBR is mainly controlled by reaction kinetics rather than diffusion.

Reaction temperature is observed to be an influential factor affecting the evolution profiles of pyrolysis gas, especially for $\mathrm{H}_{2}$ and $\mathrm{CO}$. For the same gas component, the time spent on reaching the same level of conversion fraction was gradually shortened with increasing the reaction temperature from $750{ }^{\circ} \mathrm{C}$ to $950{ }^{\circ} \mathrm{C}$. It can be also seen in Fig. 2 that during the pyrolysis of phenol, the releasing of gas components $\left(\mathrm{CH}_{4}\right.$ and
$\mathrm{CO}_{2}$ ) was found to be faster than that of $\mathrm{H}_{2}$ and $\mathrm{CO}$ due to the shorter reaction time. Therefore, a further kinetic analysis is necessary to elucidate this observation.

\section{Kinetic analysis of pyrolysis of phenol}

Table 2 illustrated the apparent activation energies $\left(E_{a}\right)$ with fitting accuracy, including the square of correlation coefficient $\left(\mathrm{R}^{2}\right)$ and standard deviation (SD) for different gas components during pyrolysis of phenol in MFBR. It can be seen in Table 2 that the apparent activation energies for all gas components increased gradually with the increased conversion fractions from $20 \%$ to $80 \%$. It is consistent with the gas evolution profiles (Fig. 2) of pyrolysis of phenol in MFBR that the reaction rate at lower conversion fractions is faster than that of higher conversion fractions. The mean value of the apparent activation energies of $\mathrm{CH}_{4}(49.67 \mathrm{~kJ} / \mathrm{mol})$ and $\mathrm{CO}_{2}(30.87 \mathrm{~kJ} / \mathrm{mol})$ were lower than that of $\mathrm{H}_{2}(145.2 \mathrm{~kJ} / \mathrm{mol})$ and $\mathrm{CO}(53.35 \mathrm{~kJ} / \mathrm{mol})$.

Table 3 - Typical reaction mechanisms for heterogeneous solid-state reaction.

\begin{tabular}{|c|c|c|c|}
\hline Symbol & Reaction mechanism & $f(x)$ & $G(x)$ \\
\hline G1 & One-dimensional diffusion & $1 / 2 \mathrm{x}$ & $x^{2}$ \\
\hline G2 & Two-dimensional diffusion (Valensi) & {$[-\ln (1-x)]^{-1}$} & $x+(1-x) \ln (1-x)$ \\
\hline G3 & Three-dimensional diffusion (Jander) & $1.5(1-x) 2 / 3[1-(1-x) 1 / 3]^{-1}$ & {$[1-(1-x) 1 / 3]^{2}$} \\
\hline G4 & Three-dimensional diffusion (G-B) & $1.5[1-(1-x) 1 / 3]^{-1}$ & $1-2 x / 3-(1-x)^{2 / 3}$ \\
\hline G5 & Three-dimensional diffusion (A-J) & $1.5(1+\mathrm{x}) 2 / 3[(1+\mathrm{x}) 1 / 3-1]^{-1}$ & {$[(1+x) 1 / 3-1]^{2}$} \\
\hline G6 & Nucleation and growth $(n=2 / 3)$ & $1.5(1-\mathrm{x})[-\ln (1-\mathrm{x})]^{1 / 3}$ & {$[-\ln (1-x)]^{2 / 3}$} \\
\hline G7 & Nucleation and growth $(n=1 / 2)$ & $2(1-x)[-\ln (1-x)]^{1 / 2}$ & {$[-\ln (1-x)]^{1 / 2}$} \\
\hline G8 & Nucleation and growth $(\mathrm{n}=1 / 3)$ & $3(1-x)[-\ln (1-x)]^{2 / 3}$ & {$[-\ln (1-x)]^{1 / 3}$} \\
\hline G9 & Nucleation and growth $(n=1 / 4)$ & $4(1-x)[-\ln (1-x)]^{1 / 3}$ & {$[-\ln (1-x)]^{1 / 4}$} \\
\hline G10 & Autocatalytic reaction & $x(1-x)$ & $\ln [\mathrm{x} /(1-\mathrm{x})]$ \\
\hline G11 & Mampel power law $(n=1 / 2)$ & $2 x^{1 / 2}$ & $x^{1 / 2}$ \\
\hline G12 & Mampel power law $(\mathrm{n}=1 / 3)$ & $3 x^{2 / 3}$ & $x^{1 / 3}$ \\
\hline G13 & Mampel power law $(n=1 / 4)$ & $4 x^{3 / 4}$ & $x^{1 / 4}$ \\
\hline G14 & Chemical reaction $(\mathrm{n}=3)$ & $(1-x)^{3}$ & {$\left[(1-x)^{-2}-1\right] / 2$} \\
\hline G15 & Chemical reaction $(\mathrm{n}=2)$ & $(1-x)^{2}$ & $(1-x)^{-1}-1$ \\
\hline G16 & Chemical reaction $(\mathrm{n}=1)$ & $1-\mathrm{x}$ & $-\ln (1-x)$ \\
\hline G17 & Chemical reaction $(\mathrm{n}=0)$ & 1 & $\mathrm{x}$ \\
\hline G18 & Contraction sphere & $3(1-x)^{2 / 3}$ & $1-(1-x)^{1 / 3}$ \\
\hline G19 & Contraction cylinder & $2(1-x)^{1 / 2}$ & $1-(1-x)^{1 / 2}$ \\
\hline
\end{tabular}

Note: A-J: Anti-Jander; G-B: Ginstling-Brounshtein. 

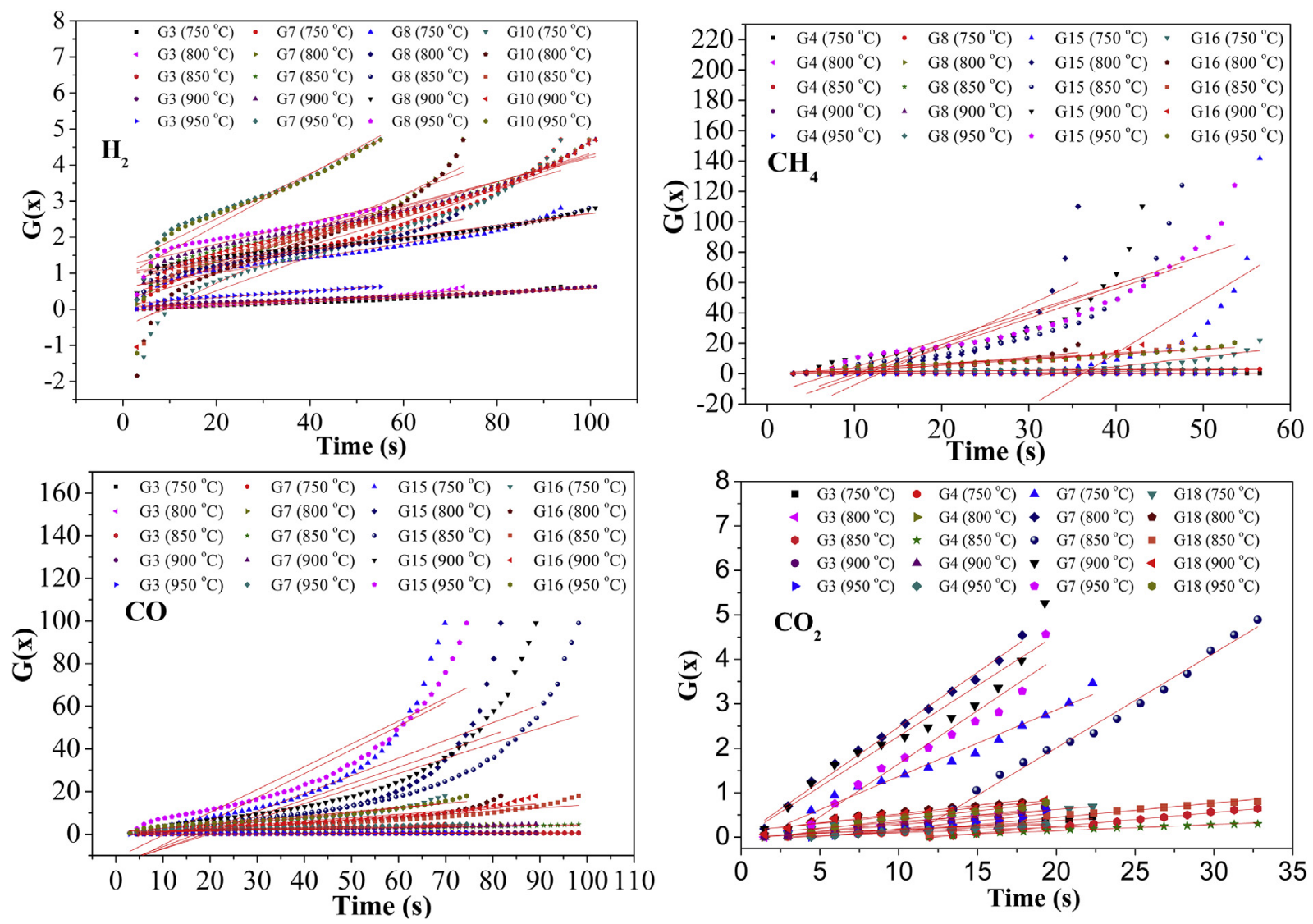

Fig. 3 - Correlation of $G(x)$ versus $t$ at different reaction temperatures for individual gas components.

A reaction with lower activation energy means less energy is required to break the chemical bonds between atoms and hence the reaction rate is faster, accompanied with a shorter residence time. Therefore, it accounts for the observation in Fig. 2 that the formation of gas components $\left(\mathrm{CH}_{4}\right.$ and $\left.\mathrm{CO}_{2}\right)$ is easier than that of $\mathrm{H}_{2}$ and $\mathrm{CO}$ during pyrolysis of phenol. Besides, the activation energies for individual gas components, 30.87-145.2 $\mathrm{kJ} / \mathrm{mol}$, are lower than, but within the range of activation energies for thermal decomposition of tar from real biomass [41,42] or tar model compounds [11,43] reported in the literature. In this study the activation energies of four gas components all varied greatly rather than remain stable at different conversion fractions. It suggests that the generation of different gaseous products during the pyrolysis of phenol may proceed with varied reaction mechanisms in the present study.

Table 3 illustrated the most common nineteen reaction models for heterogeneous solid-state reaction, which were applied in the present study $[4,38,39]$. Fig. 3 illustrated the correlation of $\mathrm{G}(\mathrm{x})$ versus $\mathrm{t}$ at different reaction temperatures for individual gas components in MFBR. Based on the fitting accuracy, the four probable reaction models (Table 4) were selected first from the nineteen reaction models shown in Table 3. Afterwards, the most probable reaction model (Table 5) can be determined from the four probable models based on the closeness of the value of apparent activation energies obtained from the universal integral method and FriedmanReich-Levi method. Table 5 verified the speculation that the formation of individual gas components proceeded with different reaction mechanisms. Specifically, the mechanism of three-dimension diffusion could describe the evolution profiles of $\mathrm{H}_{2}$ and $\mathrm{CH}_{4}$. Chemical reaction and contracting sphere are the most probable reaction mechanisms for $\mathrm{CO}$ and $\mathrm{CO}_{2}$, respectively. As pyrolysis proceeds with the conversion fractions increased correspondingly, the solid material will be decomposed from the superficial towards the center in various ways such as contracting sphere/cylinder, nucleation and growth. According to Font et al. [44], during this process, the complex physical and chemical interactions changed the composition of the reactant, and thus the active surface area of the reactant also changes due to the variations of solid depletion and pore structure. Additionally, the global reaction is the sum of various free radical reactions. The application of transition state theory $[45,46]$ that can provide more basic information regarding the reaction rates of elementary chemical reactions, needing a further investigation.

Biomass tar is a complex mixture of organic compounds. According to the literature [4,47-51], the components of tar were divided into five classes based on the molecular weight of tar compounds: (1) GC-undetectable, (2) Heterocyclic aromatics (Pyridine, phenol, cresol, quinoline), (3) Aromatics (1 ring) (Xylene, styrene, toluene), (4) Light PAH compounds (2-3 ring) (Naphthalene, biphenyl, acenaphtylene, fluorenc, phenanthrene, anthracene), (5) Heavy PAH compounds (4-7 ring) (Fluoranthene, pyrene, chrysene, benzofluoranthene, benzopyrene, perylene). During the gasification process, the 
Table 4 - Probable reaction models and kinetic parameters for individual gas during pyrolysis of phenol.

\begin{tabular}{|c|c|c|c|c|c|c|c|c|c|c|c|c|c|}
\hline Gas & Temp & $G(X)$ & G3 & G7 & G8 & G10 & Gas & Temp & $G(X)$ & G4 & G8 & G15 & G16 \\
\hline \multirow[t]{16}{*}{$\mathrm{H}_{2}$} & $750^{\circ} \mathrm{C}$ & $\mathrm{K}(\mathrm{T})$ & 0.006 & 0.039 & 0.021 & 0.047 & $\mathrm{CH}_{4}$ & $750^{\circ} \mathrm{C}$ & $\mathrm{K}(\mathrm{T})$ & 0.010 & 0.077 & 3.525 & 0.647 \\
\hline & & $\ln K(T)$ & -5.124 & -3.248 & -3.884 & -3.053 & & & $\ln K(t)$ & -4.624 & -2.566 & 1.260 & -0.436 \\
\hline & & $\mathrm{R}^{2}$ & 0.967 & 0.957 & 0.971 & 0.957 & & & $\mathrm{R}^{2}$ & 0.961 & 0.919 & 0.912 & 0.952 \\
\hline & $800^{\circ} \mathrm{C}$ & $\mathrm{K}(\mathrm{T})$ & 0.008 & 0.049 & 0.026 & 0.061 & & $800^{\circ} \mathrm{C}$ & $\mathrm{K}(\mathrm{T})$ & 0.009 & 0.066 & 2.630 & 0.521 \\
\hline & & $\operatorname{lnK}(\mathrm{T})$ & -4.896 & -3.013 & -3.635 & -2.790 & & & $\ln K(t)$ & -4.764 & -2.719 & 0.967 & -0.651 \\
\hline & & $\mathrm{R}^{2}$ & 0.965 & 0.953 & 0.962 & 0.934 & & & $\mathrm{R}^{2}$ & 0.902 & 0.908 & 0.901 & 0.926 \\
\hline & $850^{\circ} \mathrm{C}$ & $\mathrm{K}(\mathrm{T})$ & 0.005 & 0.035 & 0.017 & 0.040 & & $850^{\circ} \mathrm{C}$ & $\mathrm{K}(\mathrm{T})$ & 0.005 & 0.039 & 1.944 & 0.357 \\
\hline & & $\operatorname{lnK}(\mathrm{T})$ & -5.231 & -3.357 & -4.057 & -3.233 & & & $\ln K(t)$ & -5.327 & -3.239 & 0.665 & -1.031 \\
\hline & & $\mathrm{R}^{2}$ & 0.986 & 0.972 & 0.963 & 0.950 & & & $\mathrm{R}^{2}$ & 0.914 & 0.918 & 0.901 & 0.914 \\
\hline & $900^{\circ} \mathrm{C}$ & $\mathrm{K}(\mathrm{T})$ & 0.005 & 0.033 & 0.016 & 0.037 & & $900^{\circ} \mathrm{C}$ & $\mathrm{K}(\mathrm{T})$ & 0.005 & 0.038 & 1.814 & 0.341 \\
\hline & & $\ln K(T)$ & -5.288 & -3.410 & -4.115 & -3.289 & & & $\ln K(t)$ & -5.362 & -3.262 & 0.596 & -1.078 \\
\hline & & $\mathrm{R}^{2}$ & 0.981 & 0.965 & 0.952 & 0.937 & & & $\mathrm{R}^{2}$ & 0.902 & 0.903 & 0.901 & 0.903 \\
\hline & $950^{\circ} \mathrm{C}$ & $\mathrm{K}(\mathrm{T})$ & 0.009 & 0.063 & 0.030 & 0.071 & & $950^{\circ} \mathrm{C}$ & $\mathrm{K}(\mathrm{T})$ & 0.003 & 0.029 & 1.954 & 0.320 \\
\hline & & $\operatorname{lnK}(\mathrm{T})$ & -4.685 & -2.768 & -3.494 & -2.645 & & & $\ln K(t)$ & -5.726 & -3.559 & 0.670 & -1.138 \\
\hline & & $\mathrm{R}^{2}$ & 0.926 & 0.925 & 0.916 & 0.914 & & & $\mathrm{R}^{2}$ & 0.900 & 0.912 & 0.927 & 0.954 \\
\hline & $E_{a}$ & $\mathrm{~kJ} / \mathrm{mol}$ & 147.7 & 120.5 & 110.5 & 111.1 & & $E_{a}$ & $\mathrm{~kJ} / \mathrm{mol}$ & 47.08 & 36.78 & 55.12 & 21.53 \\
\hline \multirow[t]{17}{*}{$\mathrm{CO}$} & Temp & $G(X)$ & G3 & G7 & G15 & G16 & $\mathrm{CO}_{2}$ & Temp & $G(X)$ & G3 & G4 & G7 & G18 \\
\hline & $750^{\circ} \mathrm{C}$ & $\mathrm{K}(\mathrm{T})$ & 0.008 & 0.050 & 1.116 & 0.218 & & $750^{\circ} \mathrm{C}$ & $\mathrm{K}(\mathrm{T})$ & 0.023 & 0.012 & 0.150 & 0.028 \\
\hline & & $\operatorname{lnK}(\mathrm{T})$ & -4.884 & -2.996 & 0.109 & -1.522 & & & $\ln K(T)$ & -3.792 & -4.397 & -1.900 & -3.574 \\
\hline & & $\mathrm{R}^{2}$ & 0.969 & 0.965 & 0.918 & 0.931 & & & $\mathrm{R}^{2}$ & 0.972 & 0.993 & 0.977 & 0.968 \\
\hline & $800^{\circ} \mathrm{C}$ & $\mathrm{K}(\mathrm{T})$ & 0.007 & 0.043 & 0.763 & 0.166 & & $800^{\circ} \mathrm{C}$ & $\mathrm{K}(\mathrm{T})$ & 0.036 & 0.017 & 0.246 & 0.039 \\
\hline & & $\operatorname{lnK}(\mathrm{T})$ & -5.025 & -3.149 & -0.271 & -1.797 & & & $\ln K(T)$ & -3.313 & -4.063 & -1.402 & -3.232 \\
\hline & & $\mathrm{R}^{2}$ & 0.984 & 0.968 & 0.900 & 0.927 & & & $\mathrm{R}^{2}$ & 0.998 & 0.995 & 0.992 & 0.992 \\
\hline & $850^{\circ} \mathrm{C}$ & $\mathrm{K}(\mathrm{T})$ & 0.005 & 0.034 & 0.710 & 0.144 & & $850^{\circ} \mathrm{C}$ & $\mathrm{K}(\mathrm{T})$ & 0.031 & 0.014 & 0.213 & 0.032 \\
\hline & & $\operatorname{lnK}(\mathrm{T})$ & -5.265 & -3.382 & -0.343 & -1.939 & & & $\ln K(T)$ & -3.467 & -4.261 & -1.547 & -3.433 \\
\hline & & $\mathrm{R}^{2}$ & 0.979 & 0.965 & 0.900 & 0.905 & & & $\mathrm{R}^{2}$ & 0.997 & 0.992 & 0.991 & 0.995 \\
\hline & $900^{\circ} \mathrm{C}$ & $\mathrm{K}(\mathrm{T})$ & 0.006 & 0.037 & 0.831 & 0.163 & & $900^{\circ} \mathrm{C}$ & $\mathrm{K}(\mathrm{T})$ & 0.033 & 0.015 & 0.228 & 0.035 \\
\hline & & $\operatorname{lnK}(\mathrm{T})$ & -5.185 & -3.295 & -0.185 & -1.814 & & & $\ln K(T)$ & -3.409 & -4.178 & -1.479 & -3.341 \\
\hline & & $\mathrm{R}^{2}$ & 0.968 & 0.957 & 0.908 & 0.925 & & & $\mathrm{R}^{2}$ & 0.995 & 0.990 & 0.998 & 0.996 \\
\hline & $950{ }^{\circ} \mathrm{C}$ & $\mathrm{K}(\mathrm{T})$ & 0.006 & 0.040 & 1.071 & 0.195 & & $950^{\circ} \mathrm{C}$ & $\mathrm{K}(\mathrm{T})$ & 0.036 & 0.018 & 0.239 & 0.040 \\
\hline & & $\operatorname{lnK}(\mathrm{T})$ & -5.124 & -3.220 & 0.068 & -1.637 & & & $\ln K(T)$ & -3.792 & -4.397 & -1.900 & -3.574 \\
\hline & & $\mathrm{R}^{2}$ & 0.940 & 0.944 & 0.908 & 0.958 & & & $\mathrm{R}^{2}$ & 0.996 & 0.992 & 0.991 & 0.995 \\
\hline & $E_{a}$ & $\mathrm{~kJ} / \mathrm{mol}$ & 65.14 & 63.38 & 51.27 & 39.48 & & $E_{a}$ & $\mathrm{~kJ} / \mathrm{mol}$ & 27.67 & 26.34 & 34.51 & 31.63 \\
\hline
\end{tabular}

Bold signifies the apparent activation energy determined by the universal integral method.

increased temperature promoted the thermal decomposition of tars of class 1 and class 2, while the concentration of class 3 and class 5 tars increased conversely. According to Sun et al. [52], part of heavy tar compounds was thermal degraded to light liquid compounds at the temperature of $500-600{ }^{\circ} \mathrm{C}$. However, at higher temperatures $\left(700-800{ }^{\circ} \mathrm{C}\right)$, the tar with heavy molecular weight was very resistant to cracking although the thermal cracking was the principal reaction of tar reduction. Since the tar compound of phenol investigated in the present study belongs to Class 2, the results obtained in the present study verified those conclusions above that with the increasing of temperature from 750 to $950{ }^{\circ} \mathrm{C}$, the light tar of phenol was effectively cracked. Besides, it suggests that the approach of thermal cracking in a certain temperature is more feasible for reduction of light tar instead of heavy tar, and the increased tar yield with increased temperature may originate from tar with heavy molecule weight during the gasification process. A detailed reaction kinetic study of different classes of tar components may help us get a more comprehensive knowledge of tar reduction during gasification process, which is recommended for future study.

\section{Conclusions}

The present study investigated the pyrolysis behavior of phenol as tar model compound in the micro fluidized bed reactor. Results indicated that the cracking reaction of phenol

Table 5 - Most probable reaction models and kinetics parameters for individual gas during pyrolysis of phenol.

\begin{tabular}{lcclll} 
Gas & $\mathrm{E}_{\mathrm{a}}-\mathrm{FRL}(\mathrm{kJ} / \mathrm{mol})$ & $\mathrm{E}_{\mathrm{a}}$-UI $(\mathrm{kJ} / \mathrm{mol})$ & & Reaction mechanism & $\mathrm{G}(\mathrm{X})$ \\
\hline $\mathrm{H}_{2}$ & 145.2 & 147.7 & $\mathrm{G} 3$ & Three-dimensional diffusion (Jander) & {$[1-(1-\mathrm{x}) 1 / 3]^{2}$} \\
$\mathrm{CH}_{4}$ & 49.67 & 47.08 & $\mathrm{G} 4$ & Three-dimensional diffusion $(\mathrm{G}-\mathrm{B})$ & $1-2 \mathrm{x} / 3-(1-\mathrm{x})^{2 / 3}$ \\
$\mathrm{CO}$ & 53.35 & 51.27 & $\mathrm{G} 16$ & Chemical reaction $(\mathrm{n}=2)$ & $-\ln (1-\mathrm{x})$ \\
$\mathrm{CO}_{2}$ & 30.87 & 31.63 & $\mathrm{G} 18$ & Contraction sphere & $1-(1-\mathrm{x})^{1 / 3}$ \\
\hline
\end{tabular}

Note: FRL: Friedman-Reich-Levi method; UI: Universal Integral method. 
was favored at higher temperatures, and reaction temperature was observed to be an influential factor affecting the evolution profiles of individual gaseous products, including hydrogen, methane, carbon monoxide and carbon dioxide. Pyrolysis kinetics were then carried out based on the isoconversional and model-fitting approaches and the apparent activation energies for hydrogen, methane, carbon monoxide and carbon dioxide were $145.2 \mathrm{~kJ} / \mathrm{mol}, 49.67 \mathrm{~kJ} / \mathrm{mol}, 53.35$ and $30.87 \mathrm{~kJ} / \mathrm{mol}$, respectively. The evolution of hydrogen and methane could be described by three-dimensional diffusion while chemical reaction and contracting sphere could account for the formation of carbon monoxide and carbon dioxide, respectively.

\section{Acknowledgments}

We are grateful for financial support from National Key Foundation for Exploring Scientific Instrument (2011YQ120039).

\section{Nomenclature}

A pre-exponential factor, $\mathrm{s}^{-1}$

E apparent activation energy, $\mathrm{kJ} \cdot \mathrm{mol}^{-1}$

$\mathrm{f}(\mathrm{x}) \quad$ differential reaction model

$\mathrm{G}(\mathrm{x}) \quad$ integral reaction model

$\mathrm{k}(\mathrm{T}) \quad$ rate constant of reaction

$\mathrm{R} \quad$ universal gas constant, $8.3145 \mathrm{~J} \mathrm{~mol}^{-1} \mathrm{~K}^{-1}$

$\mathrm{t}$ reaction time, $\mathrm{s}$

$t_{0} \quad$ start time of reaction, $s$

$t_{e} \quad$ end time of reaction, $s$

$\mathrm{T}$ reaction temperature, $\mathrm{K}$

$\mathrm{V}_{\mathrm{i}} \quad$ volume rate of the gas product $\mathrm{i}$

$\mathrm{V} \quad$ volume rate of all gas products

$\mathrm{x}$ conversion fraction of gas concentration, \%

\section{R EFER E N C E S}

[1] Gordillo G, Annamalai K, Carlin N. Adiabatic fixed-bed gasification of coal, dairy biomass, and feedlot biomass using an air-steam mixture as an oxidizing agent. Renew Energ 2009;34:2789-97.

[2] Li XT, Grace JR, Lim CJ, Watkinson AP, Chen HP, Kim JR. Biomass gasification in a circulating fluidized bed. Biomass Bioenergy 2004;26:171-93.

[3] Li D, Ishikawa C, Koike M, Wang L, Nakagawa Y, Tomishige K. Production of renewable hydrogen by steam reforming of tar from biomass pyrolysis over supported Co catalysts. Int J Hydrogen Energ 2013;38:3572-81.

[4] Han J, Kim H. The reduction and control technology of tar during biomass gasification/pyrolysis: an overview. Renew Sust Energ Rev 2008;12:397-416.

[5] Lu M, Lv PM, Yuan ZH, Li HW. The study of bimetallic NieCo/ cordierite catalyst for cracking of tar from biomass pyrolysis. Renew Energ 2013;60:522-8.

[6] Li D, Koike M, Chen J, Nakagawa Y, Tomishige K. Preparation of Ni-Cu/Mg/Al catalysts from hydrotalcite-like compounds for hydrogen production by steam reforming of biomass tar. Int J Hydrogen Energ 2014;39:10959-70.
[7] Zamboni I, Zimmermann Y, Kiennemann A, Courson C. Improvement of steam reforming of toluene by $\mathrm{CO}_{2}$ capture using $\mathrm{Fe} / \mathrm{CaO}-\mathrm{Ca} 12 \mathrm{Al140} 33$ bi-functional materials. Int J Hydrogen Energ 2015;40:5297-304.

[8] Font Palma C. Modelling of tar formation and evolution for biomass gasification: a review. Appl Energ 2013;111:129-41.

[9] Devi L, Ptasinski KJ, Janssen FJJG. A review of the primary measures for tar elimination in biomass gasification processes. Biomass Bioenergy 2003;24:125-40.

[10] Gai C, Dong Y. Experimental study on non-woody biomass gasification in a downdraft gasifier. Int J Hydrogen Energ 2012;37:4935-44.

[11] Anis S, Zainal ZA. Study on kinetic model of microwave thermocatalytic treatment of biomass tar model compound. Bioresour Technol 2014;151:183-90.

[12] Kong M, Yang Q Fei J, Zheng X. Experimental study of Ni/ $\mathrm{MgO}$ catalyst in carbon dioxide reforming of toluene, a model compound of tar from biomass gasification. Int J Hydrogen Energ 2012;37:13355-64.

[13] Udomsirichakorn J, Basu P, Abdul Salam P, Acharya B. Effect of $\mathrm{CaO}$ on tar reforming to hydrogen-enriched gas with inprocess $\mathrm{CO}_{2}$ capture in a bubbling fluidized bed biomass steam gasifier. Int J Hydrogen Energ 2013;38:14495-504.

[14] Šulc J, Štojdl J, Richter M, Popelka J, Svoboda K, Smetana J, et al. Biomass waste gasification-Can be the two stage process suitable for tar reduction and power generation? Waste Manage 2012;32:692-700.

[15] Kim JW, Mun TY, Kim JO, Kim JS. Air gasification of mixed plastic wastes using a two-stage gasifier for the production of producer gas with low tar and a high caloric value. Fuel 2011;90:2266-72.

[16] Bhattacharya SC, Mizanur R, Siddique AHM, Pham HL. A study on wood gasification for low-tar gas production. Energy 1999;24:285-96.

[17] Yan L, He B, Hao T, Pei X, Li X, Wang C, et al. Thermogravimetric study on the pressurized hydropylysis kinetics of a lignite coal. Int J Hydrogen Energ 2014;39:7826-33.

[18] Gai C, Dong Y, Zhang T. The kinetic analysis of the pyrolysis of agricultural residue under non-isothermal conditions. Bioresour Technol 2013;127:298-305.

[19] Yu J, Zeng X, Zhang JW, Zhong M, Zhang GY, Wang Y, et al. Isothermal differential characteristics of gas-solid reaction in micro-fluidized bed reactor. Fuel 2013;103:29-36.

[20] Yu J, Yao CB, Zeng X, Geng S, Dong L, Wang Y, et al. Biomass pyrolysis in a micro-fluidized bed reactor: characterization and kinetics. Chem Eng J 2011;168:839-47.

[21] Yu J, Zeng X, Zhang CY, Zhang JW, Wang Y, Xu GW. Kinetics and mechanism of direct reaction between $\mathrm{CO}_{2}$ and $\mathrm{Ca}(\mathrm{OH})_{2}$ in micro fluidized bed. Environ Sci Technol 2013;47:7514-20.

[22] Richter H, Howard JB. Formation of polycyclic aromatic hydrocarbons and their growth to soot-a review of chemical reaction pathways. Prog Energ Combust Sci 2000;26:565-608.

[23] Lorente E, Milan M, Brandon NP. Use of gasification syngas in SOFC: impact of real tar on anode materials. Int J Hydrogen Energ 2012;37:7271-8.

[24] Mani S, Kastner JR, Juneja A. Catalytic decomposition of toluene using a biomass derived catalyst. Fuel Process Technol 2013;114:118-25.

[25] Swierczynski D, Courson C, Kiennemann A. Study of steam reforming of toluene used as model compound of tar produced by biomass gasification. Chem Eng Process 2008;47:508-13.

[26] Ashok J, Kawi S. Steam reforming of toluene as a biomass tar model compound over $\mathrm{CeO}_{2}$ promoted $\mathrm{Ni} / \mathrm{CaO}-\mathrm{Al}_{2} \mathrm{O}_{3}$ catalytic systems. Int J Hydrogen Energ 2013;38:13938-49.

[27] Simell PA, Hakala NAK, Haario HE. Catalytic decomposition of gasification gas tar with benzene as the model compound. Ind Eng Chem Res 1997;36:42-51. 
[28] Zhang R, Liu C, Yin R, Duan J, Luo Y. Experimental and kinetic study of the NO-reduction by tar formed from biomass gasification, using benzene as a tar model component. Fuel Process Technol 2011;92:132-8.

[29] Fuentes-Cano D, Gómez-Barea A, Nilsson S, Ollero P. Decomposition kinetics of mdoel tar compounds over chars with different internal structure to model hot tar removal in biomass gasification. Chem Eng J 2013;228:1223-33.

[30] Anis S, Zainal ZA, Bakar MZA. Thermocatalytic treatment of biomass tar model compounds via radio frequency. Bioresour Technol 2013;136:117-25.

[31] Dufour A, Girods P, Masson E, Rogaume Y, Zoulalian A. Synthesis gas production by biomass pyrolysis: effect of reactor temperature on product distribution. Int J Hydrogen Energ 2009;34:1726-34.

[32] Jess A. Mechanisms and kinetics of thermal reactions of aromatic hydrocarbons from pyrolysis of solid fuels. Fuel 1996;75:1441-8.

[33] Fagbemi L, Khezami L, Capart R. Pyrolysis products from different biomasses: application to the thermal cracking of tar. Appl Energ 2001;69:293-306.

[34] Vivanpatarakij S, Assabumrungrat S. Thermodynamic analysis of combined unit of biomass gasifier and tar steam reformer for hydrogen production and tar removal. Int J Hydrogen Energ 2013;38:3930-6.

[35] Retnamma R, Novais AQ, Rangel CM, Yu L, Matthews MA. Kinetic modeling of self-hydrolysis of aqueous $\mathrm{NaBH}_{4}$ solutions by model-based isoconversional method. Int $\mathrm{J}$ Hydrogen Energ 2014;39:6567-76.

[36] Friedman HL. Mass spectrometric thermal analysis: a review. Thermochim Acta 1970;1:199-227.

[37] Baray Guerrero MR, Marques da Silva Paula M, Meléndez Zaragoza M, Salinas Gutiérrez J J, Guzmán Velderrain V, López Ortiz A, et al. Thermogravimetric study on the pyrolysis kinetics of apple pomace as waste biomass. Int J Hydrogen Energ 2014;39:16619-27.

[38] Gai C, Zhang YH, Chen WT, Zhang P, Dong YP. Thermogravimetric and kinetic analysis of thermal decomposition characteristics of low-lipid microalgae. Bioresour Technol 2013;150:139-48.

[39] White JE, Catallo WJ, Legendre BL. Biomass pyrolysis kinetics: a comparative critical review with relevant agricultural residue case studies. J Anal Appl Pyrol 2011;91:1-33.

[40] Horn C, Roy K, Frank P, Just Th. Shock-tube study on the high-temperature pyrolysis of phenol. Twenty-seventh symposium (international) on combustion. Pittsburgh: The Combustion Institute; 1998. p. 321-8.

[41] Boroson ML, Howard JB, Longwell JP, Peters WA. Products, yields and kinetics for the vapor-phase cracking of wood pyrolysis tars. AIChEJ 1989;35:120-8.

[42] Mansaray KG, Ghaly AE. Determination of kinetic parameters of rice husks in oxygen using thermogravimetric analysis. Biomass Bioenergy 1999;17:19-31.

[43] Nowakowska M, Herbinet O, Dufour A, Glaude P. Detailed kinetic study of anisole pyrolysis and oxidation to understand tar formation during biomass combustion and gasification. Combust Flame 2014;161:1474-88.

[44] Font R, García AN. Application of the transition state theory to the pyrolysis of biomass and tars. J Anal Appl Pyrol 1995;35:249-58.

[45] Piansawan T, Kungwan N, Jungsuttiwong S. Application of the reaction class transition state theory to the kinetics of hydrogen abstraction reactions of alkanes by atomic chlorine. Comput Theor Chem 2013;1011:65-74.

[46] Zhou Y, Yin C. Applications of power-low transition state theory to the reaction of a hydroxyl radical with molecular hydrogen and the respiration in Camellia Japonica. Phys A 2015;417:267-72.

[47] Anna P, Sylwester K, Wlodzimierz B. Effect of operating conditions on tar and gas composition in high temperature air/steam gasification (HTAG) of plastic containing waste. Fuel Process Technol 2006;87:223-33.

[48] Morf P. Mechanisms and kinetics of homogeneous secondary reactions of tar from continuous pyrolysis of wood chips. Fuel 2002;81:843-53.

[49] Claes B. Characteristics of evolution of tar from wood pyrolysis in a fixed-bed reactor. Fuel 1996;75:213-9.

[50] Skoulou V, Kantarelis E, Arvelakis S, Yang W, Zabaniotou A. Effect of biomass leaching on $\mathrm{H} 2$ production, ash and tar behavior during high temperature steam gasification (HTSG) process. Int J Hydrogen Energ 2009;34:5666-73.

[51] Rhyner U, Edinger P, Schildhauer TH, Biolaz SMA. Experimental study on high temperature catalytic conversion of tars and organic sulfur compounds. Int $\mathrm{J}$ Hydrogen Energ 2013;39:4926-37.

[52] Sun Q, Yu S, Wang F, Wang J. Decomposition and gasification of pyrolysis volatiles from pine wood through a bed of hot char. Fuel 2011;90:1041-8. 